\title{
International Institutions and Civil War Prevention
}

\author{
Johannes Karreth University of Colorado Boulder \\ Jaroslav Tir University of Colorado Boulder
}

\begin{abstract}
We examine the potential of highly structured intergovernmental organizations (HSIGOs) to prevent the escalation of low-level, domestic armed conflicts in member states to civil wars. A state's membership in HSIGOs alters the bargaining game between the government and rebels by increasing the costs of escalation (e.g., via sanctions) and decreasing the amount of benefits the state hoped to receive from future international cooperation. The anticipation of such consequences provides the government with an increased interest in settling the conflict before it escalates. This in turn also mitigates an important aspect of uncertainty associated with bargaining failure, including enhancing the credibility of commitments. Empirical analyses and follow-up tests of all domestic armed conflicts from 1945 to 2000 provide robust support for the hypothesized conflict-management function of HSIGO memberships.
\end{abstract}

$\mathrm{R}$ esearchers and practitioners alike have been bewildered for decades by the problem of how to stop civil wars. ${ }^{1}$ Once a country experiences a full-fledged civil war, the chances of conflict recurrence grow substantially. Causes range from unresolved grievances, war-related enmity, and desire for revenge to the negative impact of civil wars on countries' economic and political development (Blattman and Miguel 2010). Meanwhile, traditional third-party conflict management (e.g., mediation, intervention, peacekeeping) does not appear all that effective in either stopping ongoing civil wars or preventing their recurrence (e.g., Balch-Lindsay and Enterline 2000; Doyle and Sambanis 2000; Metternich 2011). Given the problems posed by ongoing civil wars, we shift the ontological focus away from civil war management to civil war prevention. We approach civil wars from the developmental perspective and divide the life cycle of domestic conflicts into the initial, low-level armed conflict $^{2}$ phase and the later, civil war phase. This allows us to study the process of escalation and address the question of how to prevent the escalation of lowlevel domestic conflicts into full-fledged civil wars.

One illustration of escalation prevention is the example of Indonesia, where a serious crisis over the status of East Timor was defused before it turned into a civil war. When a referendum produced a clear vote for the independence of East Timor in 1999, pro-Indonesian militias and parts of the Indonesian military reacted with a violent intimidation campaign. As a part of a broad international condemnation of these attacks, intergovernmental organizations (IGOs) to which Indonesia belonged, such as the IMF and World Bank, went well beyond verbal reprimands and threatened real, tangible costs. The IGOs asserted that they would suspend aid and assistance programs and impose heavier sanctions, lest the conflict be resolved without escalation of violence (ReliefWeb 1999). After strong initial resistance, the Indonesian government troops withdrew from East Timor. Escalation to a civil war was thus averted.

While it is well established that IGOs can help resolve conflicts between member countries (Boehmer, Gartzke, and Nordstrom 2004; Oneal, Russett, and Berbaum 2003; Shannon 2009), this illustrative caseto which we return below-highlights an important role of IGOs in averting conflict escalation within member states. Our argument is that those IGOs with high degrees of institutional depth have the greatest ability to help prevent the escalation of emerging domestic conflicts into civil wars. These highly structured IGOs (HSIGOs; e.g., the IMF, Southern African

\footnotetext{
${ }^{1}$ An online appendix with supplementary material and analyses is available at http://journals.cambridge.org/jop. Replication files for the analyses performed in the study are located at http://dvn.iq.harvard.edu/dvn/dv/jkarreth.

${ }^{2}$ We use the term "conflict" below as shorthand for conflict involving armed force.
}

The Journal of Politics, Vol. 75, No. 1, January 2013, Pp. 96-109

doi:10.1017/S0022381612000898

(C) Southern Political Science Association, 2012

ISSN 0022-3816 
Customs Union, Inter-American Development Bank, IAEA) ${ }^{3}$ possess provisions to coerce state compliance with IGO policies, tools for enforcing organizational decisions and norms, and independent administrative and monitoring bodies.

HSIGOs' design and importance to member countries can help address sources of bargaining failure thought to lead to civil wars (Fearon 2007; Walter 1999, 2009). By shaping expectations that there will be HSIGO-related costs for continuing to fight (e.g., sanctions, forgoing membership benefits), HSIGOs provide important constraints under which member governments-and to some extent the rebels-are operating. The real possibility of losing benefits and incurring costs yields potent incentives to both reach and honor compromises. And reducing uncertainty by enhancing the credibility of the government's commitments to the rebels-including not to harm them once they disarm - is arguably critical for ending domestic conflicts (Simmons and Danner 2010; Walter 1999). Empirical analyses of conflicts from 1945 to 2000 support the expectation that a state's membership in larger numbers of HSIGOs significantly reduces the likelihood that a domestic conflict on its territory will escalate to a civil war, primarily by increasing the likelihood of settlement.

Among broader implications, our study demonstrates that IGOs' conflict-management roles extend beyond traditional mediation, intervention, and peacekeeping tasks. Moreover, we show that there are positive externalities to institutional design (Koremenos, Lipson, and Snidal 2001) that go beyond the original core IGO mandates (e.g., facilitating trade) to the politics of domestic conflict. And, by relying on the concept of escalation, we bring together the low-level conflict and civil war strands of the domestic conflict literature-an integrative step made even more important by the fact that internal wars have surpassed international wars as the predominant type of armed conflict (Themnér and Wallensteen 2011).

The article is organized as follows. First, we provide an overview of problems associated with civil wars, including their management. The next section develops the logic behind our expectation that memberships in HSIGOs have important domestic conflictmanaging effects. The subsequent sections present the

\footnotetext{
${ }^{3}$ The HSIGO list and information on their temporal and spatial distributions are provided in the online appendix, Table A1 and Figures A2-3. Importantly, accounting for spatial and temporal trends does not affect our findings (see Table A4) and neither does taking into account the types of countries that are likely to be HSIGO members (democratic, wealthier, trading); see also the endogeneity discussion below.
}

research design, discussion of our findings, and concluding thoughts.

\section{Causes, Consequences, and Management of Civil Wars}

Civil wars have taken well over one million lives in the 1990s alone, created devastating social and economic consequences, and generated waves of displaced persons that can destabilize neighboring countries (Salehyan and Gleditsch 2006). Causes of civil war onset are well-known: economic opportunity through available natural resources; political grievances and poverty; unstable political institutions; inaccessible terrain; large populations; and others (Collier and Hoeffler 2004; Fearon and Laitin 2003). Yet, because these factors are either naturally given conditions or represent chronic problems, a consensus on what policies may prevent civil wars remains elusive.

A different strand of research proposes that civil wars are a result of bargaining failure emanating from commitment problems (Fearon 2007; Walter 1999). Here, governments and rebels bargain over the settlement of grievances and demands, but governments in particular often cannot credibly commit to agreements. That is, governments may use their power position to renege on deals made after the rebels have disarmed, putting the rebels into an extremely vulnerable position. Scholars have suggested that carefully crafted peace agreements (Mattes and Savun 2010) or stable political institutions may reduce such commitment problems (Fearon and Laitin 2003; Goldstone et al. 2010). Turning to IGOs to help abate post-civil war commitment problems, Walter (1999) argues that peacekeepers can help assure the rebels' safety, while Simmons and Danner (2010) note the International Criminal Court (ICC) can function as a commitment device to reduce violence. Yet, because these strategies are employed to prevent civil war recurrence, they do not address the issue of preventing civil wars in the first place all that well. But they do point to IGOs' positive role in overcoming some causes of bargaining failure. We argue that the ability of IGOs to address causes of bargaining failure can be both broadened and expanded to the earlier stages of domestic conflict, where escalation to civil war may be prevented.

\section{IGOs as Conflict Managers}

On the international level, IGO-based institutional links provide important tools for consultation, grievance 
management, and the imposition of constraints (Koremenos, Lipson, and Snidal 2001), leading to lower probabilities of militarized conflict between member states (e.g., Boehmer, Gartzke, and Nordstrom 2004; Russett, Oneal, and Davis 1998). The constraint feature in particular allows IGOs to help reduce the deleterious effects of commitment problems in the bargaining process (Mitchell and Hensel 2007). ${ }^{4}$

Yet, IGOs' international conflict-management success does not seem to translate to the domain of domestic conflict. This is not for a lack of trying: IGOs have led numerous efforts to either stop ongoing civil wars or prevent their recurrence through mediation, intervention, and peacekeeping. Yet, there is little consensus regarding the effectiveness of these approaches (e.g., Balch-Lindsay and Enterline 2000; Diehl 2008; Doyle and Sambanis 2000; Fortna 2004; Regan 2002; Metternich 2011; Regan, Frank, and Aydin 2009). It is also questionable whether these activities occur early enough in the life cycle of a conflict to prevent its escalation to civil war. Peacekeeping forces are typically deployed after the civil war is over to avert its recurrence. Similarly, because mediations and interventions mostly take place later in domestic conflicts, they are arguably not that effective in preventing escalation to civil wars.

Nevertheless, IGOs can make a difference by other means. Consistent with the argument that IGOs function as commitment devices (Pevehouse 2002), postconflict governments with low domestic accountability appear to join the ICC to signal commitment to ending violence (Simmons and Danner 2010). Hafner-Burton (2005) demonstrates that preferential trade agreements with human rights clauses help improve the human rights practice of signatory states. And Donno (2010) finds that regional IGOs may be a commitment device that can draw enforcement with regard to electoral fraud. Overall, this research suggests that states' international commitments reduce the likelihood of domestic conflict.

Building upon this idea, we argue that IGOs can modify the conditions that lead to the development of civil wars in member states. We propose that HSIGOs' institutional structure, membership benefits, and leverage over member states allow them to significantly alter the anticipated consequences of domestic conflict for the government and rebels. This in turn helps address

\footnotetext{
${ }^{4}$ Bearce and Bondanella (2007) note that IGOs help socialize their members toward peaceful, cooperative interactions, but this argument cannot be directly applied to our inquiry. Rebels are not members of IGOs and thus would have little opportunity to become socialized toward cooperation.
}

problems associated with bargaining failure and prevent the escalation of lower-level conflicts to civil wars.

\section{Theoretical Argument}

Not all IGOs are alike. Loose, ad hoc type institutions with little independent decision-making power, no central monitoring, or weak enforcement capacity are unlikely to effectively constrain state behavior. In contrast, HSIGOs possess tools for enforcing organizational decisions and norms; they are capable of coercing state compliance with IGO policies, while their design is such that established procedures of the IGO cannot be swiftly overridden by a single member (Abbott et al. 2000; Boehmer, Gartzke, and Nordstrom 2004). That states voluntarily join organizations with such leverage over them suggests that states value this membership and its benefits-resources that can also be withheld as punishment for misbehavior.

In a rationalist-institutionalist logic, membership in HSIGOs directly affects the cost calculation of states with regard to its domestic and international policies. We argue that the cost-benefit logic of HSIGOs is not only relevant for issues of interstate cooperation such as trade or the environment. HSIGO-related constraints and behavioral expectations also affect how states conduct themselves domestically, even if many HSIGOs' mandates are not directly tied to conflictual issues within member states. We return to these issues after examining the process of civil war development.

\section{Conceptualizing the Development of Civil Wars}

Civil wars take time to build up. For simplicity's sake, we conceptualize this process in two stageslow-level conflict and full-fledged civil war-and focus on the government-rebel interaction. Rebels may attack first to press their demands for better treatment, economic benefits, or autonomy. Alternatively, the government may use force to enforce its will. Violent clashes between the two sides are likely to result in fatalities. In purely quantitative terms, a threshold of 25 casualties that satisfies the criteria for low-level armed conflict according to the PRIO/ Uppsala project (Gleditsch et al. 2002) can be reached quickly. ${ }^{5}$ After these first-phase eruptions of violence,

\footnotetext{
${ }^{5}$ For example, the 1953 East German action against workers' demonstrations resulted in over 150 deaths within a day while the Bloody Sunday British crackdown in Northern Ireland-and subsequent violence-resulted in a few hundred deaths.
} 
governments and rebels face the choice of mobilizing further or of trying to accommodate each other's demands. This opens up a bargaining scenario in which the government and opposition are making key decisions that have an impact on the trajectory of the conflict. If the sides want to press their case, they risk escalation of the conflict to the second, civil war stage. While the first phase of conflict may be unexpected or unplanned, the transition to the second, civil war phase typically takes more concerted action, resources, planning, strategizing, and recruiting. Importantly, the low-level phase offers an opportunity to manage the conflict before it escalates.

\section{HSIGOs and the Prevention of Domestic Conflict Escalation}

The quick nature of the first phase of the conflict does not provide much opportunity to send in mediators, intervention forces, or peacekeepers to prevent escalation, as it takes some time for the conflict to generate broader interest and for the resources to be mobilized. These approaches therefore often take place only after the conflict has reached the civil war stage. Yet, HSIGO memberships can help alter the incentive structure of the government-rebel bargaining game during the first stage of a conflict. ${ }^{6}$ By exposing the state to the risks of suffering punishment and of foregoing future fruits of international cooperation, HSIGOs increase the costs of civil war. This deterrent effect makes both escalation now and resumption of the conflict later unattractive. ${ }^{7}$ HSIGOs thus help resolve uncertainty and commitment problems typically associated with bargaining failure. We now turn to elaborating on these dynamics.

The rebel-government bargaining game takes place between at least formally unequal actors. Governments usually have access to resources that rebels can hardly procure: police, the military, fiscal authority, diplomatic channels, and others. This asymmetry of domestic politics may provide the government with some advantages. Consequently, the rebels' strategy and resolve is dependent on their expectations about

\footnotetext{
${ }^{6}$ Due to the relative ease at which the first stage of conflict occurs, we do not expect HSIGO members to experience fewer firstphase conflicts. That this is supported empirically below also implies that HSIGOs are not simply comprised of peaceful member states.

${ }^{7}$ This argument echoes the off-the-path-behavior logic (Cameron 2000; Weingast 1996), whereby institutional structures that punish misbehavior act as deterrents; this deterrent can be so effective that the actual, active involvement by the institution in the dispute is often unobserved.
}

governments' preferred and most likely choices vis-àvis the rebels. Meanwhile, in addition to the variety of domestic factors (institutions, development, geography), governments are affected by an international environment (other states, IGOs). By being more important to and having multifaceted leverage over member states, we argue that, compared to other IGOs, HSIGOs have a particular ability to constrain member states in their behavior. The main purpose of HSIGOs such as regional trade organizations is to tie states' hands to enable cooperation between states, providing a stable, predictable environment in which trade can flourish. Yet, the instability from within member states can create uncertainty that deters economic partners, and thus damage the institution's goal. HSIGOs hence have a vested interest in the stability of member states, including the avoidance of civil wars.

Because HSIGOs have the power to impose costly sanctions and deny valuable privileges in order to protect their missions and restore confidence and normalcy, member governments that permit domestic unrest to escalate into a civil war can expect serious sanctions. ${ }^{8}$ That is, HSIGO memberships alter the rebel-government bargaining game by increasing the costs of war. Aware of such consequences, member governments are constrained and will be more interested in striking an escalation-avoiding bargain with the rebels. These constraints both reduce uncertainty about the government's optimal strategy, and they increase the credibility of a government's current commitment to resolve a conflict without escalation. In contrast, an isolated government faces weaker deterrents against pursuing the fight; rebels then confront higher uncertainty with regard to the government's path of action.

Furthermore, a state's continued good standing within HSIGOs promises future gains-a portion of which could be distributed to the rebels to make peace more attractive to them-through cooperation in economic and other affairs. Collier et al. (2003) have previously pointed to the importance of prospective economic development as a political stabilizer; future trade is particularly important in this regard, per Collier and Hoeffler (2004). But benefits from trade, aid, or investment require signals that the society will remain a stable host and partner. These carrots require the rebels and government to manage their differences,

\footnotetext{
${ }^{8}$ While HSIGOs may not prefer nonescalation in every single case (e.g., Libya in 2011), in most cases HSIGOs want stability in order to carry out their economic or security-related functions. That exceptions are not that frequent is borne out by our findings; otherwise, the HSIGO coefficient would be insignificant in our empirical tests.
} 
which may be no easy feat. Nevertheless, unlike states that are only poorly integrated into international structures, HSIGO members face tangible incentives for forgoing conflict escalation.

Importantly, the threat of HSIGO-imposed costs not only alters the nature of the bargaining game in the present time, but it also arguably constrains the government against taking escalatory actions in the future-including reneging on promises to end the conflict and not destroy the rebels after they disarm. HSIGOs' ability to punish the government down the road reduces the rebels' uncertainty about the government's future actions and addresses significant problems posed by the bargaining game, credible commitments and uncertainty (Walter 1999; see also Fortna 2004; Hoddie and Hartzell 2003). Via the threat of future costs for reneging on promises to stop the fight and for harming disarmed rebels, HSIGOs can provide implicit assurances that the government will continue to honor its commitments. Knowing that the government faces this constraint helps reassure the rebels that the government has a meaningful incentive to abide by a peace deal. ${ }^{9}$ A state's participation within HSIGOs and HSIGOs' ability to impose costs are therefore tangible and credible signals to domestic groups that the government is a reliable partner in avoiding conflict resumption and escalation. This reduces the uncertainty faced by the rebels substantially and makes them more likely to be willing to trust that the government's commitments are credible. It will therefore be easier for the rebels to lay down their arms when they are dealing with an HSIGO-embedded government. Rooted in the costs that come with returning to violence, HSIGO memberships thus reduce both uncertainty and commitment problems.

Continuing to examine the bargaining scenario with regard to rebels' incentives, even though they are not formal members of IGOs, rebels themselves are not immune from HSIGO influence and can actually cause damage to their cause by overplaying their hand. ${ }^{10}$ As the disadvantaged actor in the asymmetric

\footnotetext{
${ }^{9}$ Reneging on domestic peace deals will also entail external reputational costs with other HSIGO member states. Thus, the state has a vested interest in protecting its standing abroad by honoring its commitments at home.

${ }^{10}$ HSIGOs' ability to constrain the government does not necessarily mean that the HSIGOs are on the rebels' side politically. The rebels have to be careful that their combat conduct not put them in jeopardy of later international prosecution. HSIGO memberships therefore provide another incentive for the rebels to avoid escalation.
}

domestic bargaining situation, the rebels benefit from the state's HSIGO involvement: it provides a counterweight that constrains the state and increases the state's willingness to settle. Presumably, the settlement would be beneficial to the rebels because it represents a revision of the status quo against which they rebelled in the first place. Conversely, if the rebels appear unwilling to settle the conflict, or want to renege on their escalation-avoiding commitments, they signal to the HSIGO environment that they cannot be counted on as a partner in managing the respective conflict. As a consequence, the HSIGOs would see little value in pushing for an unlikely agreement and cease putting pressure on (i.e., constraining) the government. This then puts the rebels back into the unenviable asymmetric bargaining situation, where their path to government concessions is a costly and uncertain fight. And even if they can force the government into concessions, without the HSIGO support the rebels will have few guarantees that the government will comply in the long run; this is the familiar commitment problems scenario that is disadvantageous to the rebel side. Therefore, the state's HSIGO memberships imply that the optimal strategy for the rebels is to settle with the government before violence escalates; this gives the rebels the ability to utilize the HSIGOs to pressure the government toward both settling and keeping its commitments. As discussed below, it is hard to imagine that the IMF and World Bank would have taken such a crucial role in East Timor had active rebel groups pursued the armed struggle against Indonesia.

In sum, by increasing the costs of conflict and of reneging on settlements, HSIGO memberships provide incentives for both the rebel and government sides to resolve their bargaining game and thus avoid escalating the conflict to the civil war stage. We expect that HSIGO conflict-management effects will be the greatest when a state is simultaneously a member of multiple HSIGOs. This embeddedness in a network of highly structured institutions will help reinforce each HSIGO's conflict-management function, make penalties more multifaceted and severe, and provide more rewards for desirable behavior such as honoring commitments. It also increases the chances that at least one HSIGO will take interest in the conflict-strengthening the anticipation that actual sanctions will be forthcoming and decreasing the uncertainty with respect to commitment issues. In hypothesis form, our key expectation is,

H1: Domestic low-level armed conflicts are less likely to escalate into civil wars in those states that are more embedded in the HSIGO environment. 


\section{Research Design}

\section{The Universe of Cases, Unit of Analysis, and the Dependent Variable}

We test Hypothesis 1 on all cases of domestic armed conflict, 1945-2000. We define armed conflict as the occurrence of politically motivated violence within a country resulting in at least 25 battle deaths within one year (Themnér and Wallensteen 2011). To distinguish between multiple conflicts that are ongoing within one country at the same time, but in different regions and/or with different rebel groups, we specify as the unit of analysis a coherent dyadic episode of domestic armed conflict. We count episodes as different if violence has stopped between them or if the rebel groups change. These criteria are applied in the Non-State Actor Data from Cunningham, Gleditsch, and Salehyan (2009), an actor-specific version of the UCDP/PRIO Armed Conflict Table.

Our dependent variable, escalation, delineates whether an armed conflict episode escalated into a full-fledged civil war. We code escalation as 1 if the conflict surpassed 1,000 casualties, a long-standing threshold in the civil war literature. If the conflict ended (per UCDP/PRIO criteria) without reaching the threshold, escalation is coded as 0 . We used data from Sarkees (2000, Version 3.0) and Lacina and Gleditsch (2005) for these coding decisions. About one-third of conflicts escalated.

\section{Embeddedness in the (HS)IGO Environment}

The more HSIGOs a state is an active member of, the more embedded it is in a network of HSIGOs. This requires distinguishing HSIGOs from less institutionalized IGOs. Boehmer, Gartzke, and Nordstrom (2004) classify Pevehouse, Nordstrom, and Warnke's (2004) original IGO list by organizational structure and institutionalization. Low-structure IGOs (LSIGOs) may have a central secretariat, but no substantial bureaucratic infrastructure. Medium-structure IGOs (MSIGOs) have a bureaucracy, but no ability to adjudicate, mediate, or coerce member states. HSIGOs "contain mechanisms for mediation, arbitration and adjudication, and/or other means to coerce state decisions (such as withholding loans or aid), as well as means to enforce organizational decisions and norms" (Boehmer, Gartzke, and Nordstrom 2004, 18).

A state's count of each IGO membership type enters the analyses as a separate variable, capturing the state's entire IGO portfolio. This way, we can ascertain whether conflict-management effects are attributable specifically to HSIGO memberships. On average, states have 15 LSIGO, 6 MSIGO, and 12 HSIGO memberships; almost all states have at least one membership in each IGO type. These and other right-hand-side variables are measured in the year in which the low-level conflict starts.

\section{Control Variables}

We control for a number of factors drawn from the literature on domestic conflict onset. We measure economic development as the log of GDP per capita, using data from Gleditsch (2002). To capture regime types, we include a country's linear and squared Polity IV score (Marshall and Jaggers 2002). We also include the $\log$ of a state's population (Gleditsch 2002) as well as an indicator for mountainous terrain, per Fearon and Laitin (2003). Finally, we control for two factors potentially related to escalation. First, we account for the possible severity of grievances and oppositions' ability to mobilize by including the logged size of the population that is excluded from the national political arena (from Cederman, Min, and Wimmer 2009). Second, we account for prior settlement by noting if a country experienced a conflict settlement in the last 10 years, using data from Cunningham, Gleditsch, and Salehyan (2009).

\section{Methods of Analysis}

Given the dichotomous structure of the dependent variable, we estimate logit models with clustered standard errors to correct for the observations from the same country being related. Our main findings are verified with a probit selection model (Heckman 1979), which assesses HSIGOs' impact on escalation while accounting for the process that leads to the emergence of low-level violence in the first place.

In the Heckman analyses, country-year becomes our unit of analysis; control variables remain unchanged, except that their values are now recorded for each year under scrutiny. Some control variables may be more important for the occurrence of low-level conflict than escalation and thus help identify the selection models. Fuel exports are a structural factor that, because of the windfall gains to be made from it, renders political violence a more attractive strategy than peaceful political contest. Huntington's argument about the structural predisposition of Muslim societies for violence also applies to the occurrence of armed conflict, but it does not speak directly to the 
escalation to civil wars. And ethnic fractionalization may increase the opportunity that one group initiates protest. These three variables come from the standard study of domestic conflict onset, Fearon and Laitin (2003). Finally, we include an indicator for conflict onset in the past 10 years. For identification, we include these four variables only in the selection equation; in separate tests we also added them to the escalation equation - with no appreciable impact on the findings (see footnote 15).

\section{Findings and Discussion}

Table 1 presents the results. Initial evidence in favor of the hypothesis can be seen in Model 1, where the HSIGO coefficient is negative and significant. Greater embeddedness in the HSIGO environment makes a country less likely to experience the escalation of lower-level armed conflict into civil war.

An example of this pattern is found in the conflict between the ETA and the Spanish government. The 1980-81, 1987, and 1991-92 low-level conflicts never escalated to civil wars, with Spain having 21-26 HSIGO memberships; the global mean and median are 12. In less-developed parts of the world, ${ }^{11}$ Venezuela's conflict with splinter military groups and Mexico's fight with the EZLN stopped short of civil war, with each country having 20 HSIGO memberships. In Africa, Ghana and Cameroon each experienced conflicts with renegade military factions that did not escalate while Uganda witnessed a nonescalated conflict with the UPDA in the 1980s; each country had 17 HSIGO memberships.

Conversely, countries poorly integrated into HSIGO structures are at much greater risk of escalation of their rebellions to civil wars. Some examples include Bosnia (Serb minority), Mozambique (Renamo), Angola (UNITA), and North Yemen (opposition; Royalists), with each country having five or fewer memberships. Other instances of escalation to civil war can found in Tajikistan (UTO, 6 HSIGO memberships), Georgia (Abkhazia, 8), Rwanda (Watusi, 6), and Laos (Pathet Lao, 7) - and in other countries with below average numbers of HSIGO memberships such as Azerbaijan (Nagorno Karabakh, 10) and South Yemen (Socialist Party faction, 10). The recent example

\footnotetext{
${ }^{11}$ Excluding the low-level conflicts in the UK (N. Ireland), Spain (ETA), and the United States (Puerto Rico, 1950) did not alter the results. Neither did controlling for spatial and temporal HSIGO membership trends (see Table A4).
}

of Syria also aptly demonstrates how difficult it is for the international community to prevent conflict escalation in a country that is not all that well integrated into international institutions (11 HSIGO memberships in 2012). ${ }^{12}$

Returning to Table 1, we find no association between escalation and states' embeddedness in MSIGOs and LSIGOs. ${ }^{13}$ This implies that conflict-management benefits apply specifically to HSIGOs and are not a function of just the sheer number of IGO memberships of a state experiencing low-level armed conflict. ${ }^{14}$ The HSIGO finding holds while controlling for a variety of factors, included in the more fully specified Model 2. Significant control variables behave predictably. Consistent political institutions and past positive conflict resolution experiences prevent escalation. Meanwhile, conflicts in mountainous states and in countries where larger groups are politically excluded are more likely to escalate. ${ }^{15}$

Concerning HSIGO's substantive impact, Figure 1 presents the predicted probability of escalation based on Model 2. As HSIGO memberships increase, the risk of escalation decreases notably and continuously. If HSIGO memberships move from the $20^{\text {th }}$ to the $80^{\text {th }}$ percentile (from 9 to 16 ), the probability of escalation is cut in half, from $50 \%$ to $25 \%$. In the following pages, we provide additional evidence in favor of our argument and further probe our main finding.

\section{Illustrative Example: Political Unrest in Indonesia (1999)}

The unrest in East Timor helps illustrate the details behind our statistical findings, highlighting the role

\footnotetext{
${ }^{12}$ Following an anonymous reviewer's comment, we found the HSIGO effect to be somewhat smaller for personalist than nonpersonalist regimes ( 21 vs. 28 percentage point reduction in the probability of escalation).

${ }^{13}$ Further tests alleviate concerns that including all three IGO variables may induce multicollinearity and unduly affect our inferences. The variance inflation factors of 4-4.5 are below the usual cut-off values of 5 or 10 . Additionally, the findings do not change when (1) the HSIGO variable is used by itself (it remains significant) or (2) dropped from the model (the MSIGO and LSIGO variables remain insignificant).

${ }^{14}$ Conducting analyses with count variables for states' memberships in security, economic, and social IGOs revealed that mandates were unrelated to the escalation of domestic conflict.

${ }^{15}$ Adding the fuel exports, share of the Muslim population, ethnic fractionalization, and past conflict variables did not change the results with regards to the HSIGO variable and neither did controlling for the government's repressive capacity using the CINC score (gathered from the EUGene software; cf. Bennett and Stam 2000).
} 
Table 1 Logit and Heckman Probit Analyses of Domestic Conflict Escalation

\begin{tabular}{|c|c|c|c|c|c|}
\hline \multirow{2}{*}{ Estimator } & & \multicolumn{2}{|c|}{ Logit } & \multicolumn{2}{|c|}{ Heckman Probit } \\
\hline & & (1) & $(2)$ & (3) & (4) \\
\hline \multirow[t]{21}{*}{ y2: Escalation (Outcome) } & HSIGOs & $-0.162^{*}$ & $-0.169^{\star}$ & $-0.093^{\star}$ & $-0.098^{\star}$ \\
\hline & & $(0.067)$ & $(0.075)$ & $(0.041)$ & $(0.049)$ \\
\hline & MSIGOs & 0.067 & 0.06 & 0.049 & 0.044 \\
\hline & & $(0.071)$ & $(0.07)$ & $(0.041)$ & $(0.043)$ \\
\hline & LSIGOs & 0.017 & 0.041 & 0.005 & 0.025 \\
\hline & & $(0.03)$ & $(0.039)$ & $(0.018)$ & $(0.023)$ \\
\hline & Polity & -0.009 & -0.006 & -0.009 & -0.005 \\
\hline & & $(0.03)$ & $(0.033)$ & $(0.02)$ & $(0.02)$ \\
\hline & Polity (sq.) & $-0.012^{*}$ & $-0.012^{\star}$ & $-0.007^{\star}$ & -0.006 \\
\hline & & $(0.004)$ & $(0.005)$ & $(0.004)$ & $(0.008)$ \\
\hline & GDP p.c. (logged) & -0.206 & -0.242 & -0.074 & -0.086 \\
\hline & & $(0.160)$ & $(0.184)$ & $(0.139)$ & $(0.187)$ \\
\hline & Population (logged) & & -0.148 & & -0.084 \\
\hline & & & $(0.13)$ & & $(0.193)$ \\
\hline & Mountains (logged) & & $0.291^{\star}$ & & 0.154 \\
\hline & & & $(0.151)$ & & $(0.1)$ \\
\hline & Excluded pop. (logged) & & $0.219^{\star}$ & & $0.155^{\star}$ \\
\hline & & & $(0.096)$ & & $(0.069)$ \\
\hline & Settlements (past 10 yrs.) & & $-1.035^{\star}$ & & -0.526 \\
\hline & & & $(0.612)$ & & $(0.365)$ \\
\hline & Constant & $2.85^{\star}$ & 3.1 & $1.59^{\star}$ & 1.53 \\
\hline \multirow[t]{25}{*}{ y1: Low-Level Conflict (Selection) } & HSIGOs & & & 0.023 & 0.024 \\
\hline & & & & $(0.016)$ & $(0.016)$ \\
\hline & MSIGOs & & & -0.004 & -0.004 \\
\hline & & & & $(0.016)$ & $(0.016)$ \\
\hline & LSIGOs & & & -0.012 & -0.013 \\
\hline & & & & $(0.008)$ & $(0.008)$ \\
\hline & Polity & & & 0.01 & 0.009 \\
\hline & & & & $(0.006)$ & $(0.006)$ \\
\hline & Polity (sq.) & & & $-0.005^{\star}$ & $-0.005^{\star}$ \\
\hline & & & & $(0.001)$ & $(0.001)$ \\
\hline & GDP p.c. (logged) & & & $-0.155^{\star}$ & $-0.146^{\star}$ \\
\hline & & & & $(0.053)$ & $(0.062)$ \\
\hline & Population (logged) & & & $0.121^{\star}$ & $0.134^{\star}$ \\
\hline & & & & $(0.035)$ & $(0.034)$ \\
\hline & Mountains (logged) & & & 0.037 & 0.034 \\
\hline & & & & $(0.029)$ & $(0.027)$ \\
\hline & Ethnic fractionalization & & & 0.204 & 0.207 \\
\hline & & & & $(0.211)$ & $(0.311)$ \\
\hline & Fuel Exports & & & $0.23^{\star}$ & 0.236 \\
\hline & & & & $(0.119)$ & $(0.148)$ \\
\hline & Muslim population & & & $0.002^{\star}$ & $0.002^{\star}$ \\
\hline & & & & $(0.001)$ & $(0.001)$ \\
\hline & Conflict (past 10 yrs.) & & & $0.24^{\star}$ & $0.239^{\star}$ \\
\hline & & & & $(0.07)$ & $(0.071)$ \\
\hline & Constant & & & $-1.84^{*}$ & $-2.02^{*}$ \\
\hline \multirow[t]{4}{*}{ Correlation } & $\rho$ & & & -0.15 & -0.15 \\
\hline & $p(\rho \neq 0)$ & & & 0.79 & 0.91 \\
\hline & Log-likelihood & -143.7 & -132.3 & -987.9 & -967.9 \\
\hline & Observations & 232 & 222 & 5820 & 5817 \\
\hline
\end{tabular}

Note: Clustered standard errors in parentheses. ${ }^{\star} p<0.05$. 


\section{Figure 1 Predicted Probabilities of Escalation and Settlements}

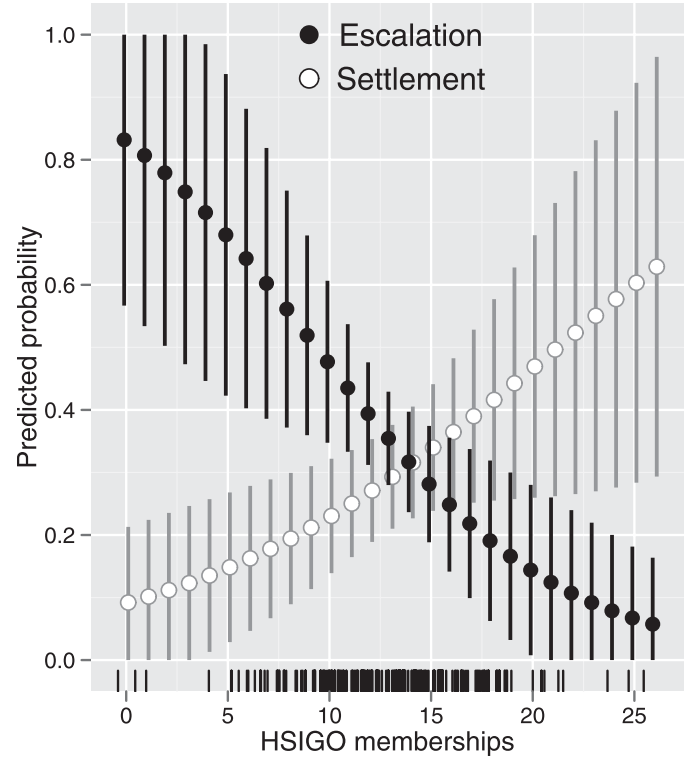

Note: The plot shows the predicted probabilities of low-level conflicts escalating (black, based on Model 2) and being settled (gray, based on Model 8). The vertical lines mark the $95 \%$ confidence intervals. $\mathrm{X}$-axis tick marks indicate the observed cases.

of HSIGOs in preventing the outbreak of a full civil war. When the violent campaign of the Indonesian military and militias against the Timorese opposition began, the international community responded relatively quickly, demanding that the Indonesian government guarantee the security of the Timorese population. According to observers, among various types of rebuke, "the most effective weapon in squeezing Indonesia was the threat of financial sanctions" (Wheeler and Dunne 2001, 819).

Importantly, these sanctions involved HSIGOs. Indonesia's membership in 18 HSIGOs puts the predicted threat of escalation at 31\% per our model. We focus on the IMF and the World Bank, the two HSIGOs that were especially important for Indonesia in the aftermath of the financial crisis. The Indonesian government had made a clear commitment to these institutions to manage the Timorese desire for independence peacefully. A September 7 World Bank report notes this commitment and states that "following through the [Indonesian government's] statement made [at the Consultative Group for Indonesia's meeting] is a critical component of the policy commitment of the Government of Indonesia, setting the context in which the program of international assis- tance agreed in July is to be realized" (ReliefWeb 1999). This exemplifies the preference (and demand) of HSIGOs for domestic stability; it also illustrates that-in this case-HSIGOs may request a formal commitment of member states to the peaceful management of domestic tensions.

As the (government-sanctioned) violence was on the verge of escalating, the IMF and World Bank first expressed grave concern about the continuation of their programs. Representatives from the IMF and the World Bank went on record in regional media stating clear conditions for short-term loans and longer-term aid (BBC News 1999). Without a clear move of the government to end the violence in East Timor, the Indonesian economy would suffer dramatically from the withdrawal of aid funds, loans, and looming currency problems. On September 13, the World Bank suspended all loans and operations (Thornton 1999), and on September 16, the IMF followed (International Monetary Fund 1999).

What prompted the HSIGO involvement? First, the Southeast Asian recovery from the 1997 financial crisis was in jeopardy; violence would have disrupted the HSIGOs' mandate. Second, the HSIGO programs in Indonesia were in danger of being used by the government to continue the violent campaign (Orford 2003, 22). Third, U.S. President Clinton called for action from HSIGOs and used them as a channel for influence (Wheeler and Dunne 2001). Importantly, our argument does not dismiss the role of third parties in domestic conflicts; rather, we highlight the importance of HSIGOs as a dimension of pressure for escalation prevention; states can certainly exploit this. In this case though, Martin notes that the World Bank and IMF's actions were "not the result of U.S. pressure; although they must have been aware of the wishes of donor countries, the respective [HSIGOs'] presidents must be credited with their strong responses to the destruction of East Timor" $(2001,108)$. And fourth, nonstate East Timor advocacy organizations turned to the HSIGOs for help in protecting the East Timorese from Indonesian militias (Aslam 1999). In sum, the HSIGOs had an interest in the stability of this member country.

The impact of HSIGOs is well documented. Contemporary observers noted that HSIGO pressure was "instrumental" in helping prevent the escalation of violence in East Timor (Fidler and Robinson 1999; cited in Wheeler and Dunne 2001, 819; also see Human Rights Watch 1999). Other contemporary news reports also note the impact of the threats of suspending HSIGOs' assistance and the resulting economic disaster on Indonesian leaders, foremost 
President Habibie (Hajari 1999). The head of the Indonesian central bank coyly stated, "I have never said it will not have any impact on us if the IMF suspends loans"; rating agencies put Indonesia's government debt on "credit-watch negative" (Thornton 1999). The demonstrable impact of HSIGO pressure on the cost of escalation is noteworthy.

Finally, we briefly highlight the role of HSIGOs following the conclusion of initial low-level violence. The World Bank, IMF, and other organizations took a key role in managing East Timor's transition to independence, stating their readiness to provide assistance to both sides early in the tensions over East Timorese independence (ReliefWeb 1999). This illustrates the importance of HSIGO involvement for rebels as well. The Timorese side knew that by far the "cheaper" strategy to attain their goal of independence was to use the assistance from these HSIGOs, rather than to escalate to a costly war with the Indonesian government. This opportunity for the opposition existed primarily because Indonesia had strong HSIGO ties, which paved the way for the HSIGOs' interest and involvement in the first place.

In sum, the case highlights key mechanisms of our argument. The early signals from HSIGOs clarified the constraints under which the Habibie government was operating: escalation would cause the denial of outside resources, and a lack of effort to prevent escalation did lead to costly HSIGO responses. In addition to the stick, the HSIGOs did announce and eventually provide support to government and opposition when Habibie backed down. This shows how HSIGOs' influence over the distribution of costs and benefits can factor into the calculations of governments and rebels with respect to escalating a violent conflict. Next, we discuss further large- $\mathrm{N}$ tests to explore the robustness of our findings.

\section{Selection Effects}

Mirroring the logit results, the Heckman selection Models 3-4 in Table 1 reveal that HSIGO memberships are negatively and significantly associated with escalation to civil war. The HSIGO coefficient is, however, insignificant in the selection equation, perhaps because HSIGOs exercise countervailing pressures on the chances of low-level conflict onset. While a state's memberships in HSIGOs may help reduce grievances that motivate rebellion (discrimination, repression, etc.), potential rebels may also view the state's institutional memberships as a means of extracting concessions from the government. ${ }^{16}$ Fausett and Volgy (2010) similarly argue that IGOs can actually invite low-level conflict between members before institutional mechanism prevent escalation.

More populous countries are at a higher risk of experiencing lower-level violence (e.g., Raleigh and Hegre 2009), and consistent democracies and autocracies are less likely to experience political violence in the first place. Additionally, economic development decreases this risk while larger Muslim populations, fuel exports, and prior conflict history all increase it (see Collier and Hoeffler 2004; Fearon and Laitin 2003). We find no evidence of significant correlation between selection and outcome equations in Models 3-4 $(\rho \neq 0, p=0.79$ and 0.91$)$, rejecting the possibility that sample selection biases our test of Hypothesis 1.

\section{External Mediation and Intervention}

Above, we assumed that external mediations and interventions are rarely employed to manage a conflict before it escalates to a civil war. We probe this assumption using data on interventions and mediation initiatives (Regan 2002; Regan et al. 2009). ${ }^{17}$ First, comparing the timing of interventions and mediations (at the median of 23 months and 48 months into a conflict) with the median duration of nonescalated conflicts (12 months) suggests that both mediations and interventions are more likely to happen in the civil war, as opposed to the low-level phase of the conflict. This is consistent with Greig (2005) and Greig and Regan (2008), who find that mediation attempts rarely occur in the early phases of conflicts.

Second, to our regression analyses we add variables reporting the number of mediations and military interventions taking place before the conflict escalated. ${ }^{18}$ HSIGOs' impact on escalation remains unaffected; see Model 5 in Table 2, which offers a

\footnotetext{
${ }^{16}$ Indeed, our bargaining argument implies that because HSIGO membership increases the cost of civil war for the government, rebels may exploit its reluctance to escalate by making stronger demands. Given that secessionist demands are particularly challenging for governments (see Walter 1999), we explored whether states with higher HSIGO memberships face such demands; the significant association $(p=0.002)$ fits with cases of countries with many HSIGO memberships that experience low-level violence over territory, such as the United Kingdom and Spain.

${ }^{17}$ Because these data cover only conflicts with over 200 casualties, these analyses serve as preliminary insights.

${ }^{18}$ Yearly battle-deaths data (Lacina and Gleditsch 2005) help us identify when the deaths exceeded 1,000.
} 
TABLE 2 Estimates for the HSIGO Coefficient in Different Robustness Checks (Summary)

\begin{tabular}{|c|c|c|c|c|}
\hline Model Number & Robustness Check & HSIGO Coefficient & $N$ & Model $\chi^{2}$ \\
\hline (5) & $\begin{array}{l}\text { Controlling for mediation and intervention } \\
\text { attempts }\end{array}$ & $-0.107^{\star}(0.045)$ & 119 & $17.64^{*}$ \\
\hline (6) & Instrumenting ${ }^{a}$ the HSIGO variable & $-0.09^{\star} \quad(0.041)$ & 221 & $26.67^{\star}$ \\
\hline (7) & $\begin{array}{l}\text { Replacing the HSIGO variable with } \\
\text { Cost-Benefit HSIGO variable }\end{array}$ & $-0.092^{\star}(0.053)$ & 222 & $25.44^{\star}$ \\
\hline (8) & $\begin{array}{l}\text { Changing the dependent variable to } \\
\text { settlement (1) vs. military victory } \\
\text { or escalation (0) outcomes }\end{array}$ & $0.108^{\star}(0.054)$ & 198 & $28.56^{\star}$ \\
\hline
\end{tabular}

Note: The dependent variables are low-level conflict escalation (Models 5-7) and settlement (Model 8). The HSIGO column reports logit (Models 5, 7, and 8) and instrumental variable probit (Model 6) coefficients; clustered standard errors are in parentheses. All other predictor variables for each model are omitted from the table to conserve space.

${ }^{\star} p<0.05$.

aModel 6 instruments: Polity score, GDP per capita (logged), trade (logged), years since last domestic conflict (logged).

brief summary of the results for the HSIGO variable based on several follow-up analyses. The interventions coefficient is insignificant while the mediations one is only weakly significant. The marginal impact is $-2 \%$ for mediations and $-50 \%$ for HSIGOs. The small effect of mediations is unsurprising given the pattern of few mediations attempts taking place early on in the conflict. In sum, these findings support our argument that HSIGO embeddedness is a more effective means of conflict escalation prevention than mediation or intervention.

\section{Endogeneity of HSIGO Memberships}

A potential concern is that if only certain types of countries (e.g., peaceful ones) are allowed to or choose to join HSIGOs, it would falsely appear that HSIGOs are effective conflict managers when in fact it is the same conditions that lead to both HSIGO memberships and a reduced risk of conflict escalation. Further empirical analyses alleviate the concern. We estimated an instrumental variable probit equation of the probability of escalation, where HSIGO memberships were instrumented by factors thought to predict which states join HSIGOs: the Polity score, logged GDP per capita, logged trade value, and logged years since last domestic conflict. ${ }^{19}$ The Wald statistic ( $p=0.28)$ yields no evidence to assert endogeneity of HSIGO memberships to the other variables in the model. Meanwhile, the HSIGO coefficient based on the instrumented HSIGO value remains negative and significant (Model 6, Table 2). This strongly suggests

\footnotetext{
${ }^{19}$ Importantly, none of these variables are directly related to our main dependent variable, escalation.
}

that HSIGOs have an exogenous conflict-management impact.

\section{HSIGO Characteristics}

The causal mechanism behind HSIGOs' anticipatory conflict-management effects invokes their ability to withhold benefits and impose costs on its members. Because some HSIGOs may perform only coordinating functions (e.g., setting standards), we restrict our HSIGO variable to organizations that have the actual ability to provide material benefits or impose costly sanctions on members; see Table A1 for the list. Replacing the original HSIGO variable with these "cost-benefit" HSIGOs continues to yield a negative and significant coefficient (Model 7, Table 2). This buttresses the argument that HSIGOs' conflict-managing effects rest on their ability to impose costs on and reward member states.

\section{Credible Commitments and Settlements}

Next, we evaluate whether HSIGO memberships are actually linked with desirable conclusions of domestic conflicts, formal or informal settlements. If governments with strong HSIGO ties are indeed more credible opponents, low-level conflicts should not only not escalate, but they should also be settled successfully. Accordingly, we distinguish between two types of low-level conflict outcomes: (a) decisive military victories before escalation and escalation regardless of the eventual outcome versus (b) conflicts ending before escalation through peace agreements or ceasefires (using the UCDP Conflict Termination data from Kreutz 2010). HSIGO memberships double the 
likelihood of the settlement outcomes (see Table 2, Model 8, and Figure 1). ${ }^{20}$ The finding corroborates HSIGOs' role as a commitment device in domestic bargaining scenarios.

\section{Rebel Characteristics}

Does the beneficial effect of HSIGOs still hold when we vary the rebel side of the bargaining game, in which they are typically structurally weaker? First, we consider the impact of rebel strength. As a control variable, rebel strength is not associated with the probability of escalation ( $p=0.24)$, while HSIGOs' impact is unaffected. Second, we investigate whether a more complex bargaining game with multiple rebel groups is more likely to result in bargaining failure and escalation. This was not the case $(p=0.83)$. Third, we explore the role of rebel financing sources, questioning whether rebels' access to lootable resources might undercut the benefits of HSIGO embeddedness. While access to gemstones and hydrocarbons is indeed associated with higher escalation risk, HSIGO links substantially reduce that risk; see Table A5. ${ }^{21}$ An initial exploration of these issues thus suggests that our primary findings hold.

\section{Conclusion and Implications}

Given the problems associated with civil wars, this project focuses on their prevention. We argue that HSIGO memberships can help resolve the rebelgovernment bargaining game, by providing antiescalation incentives and improving the credibility of commitments. Our analyses link HSIGO memberships to lower likelihoods of escalation and suggest that the findings are driven by HSIGOs' ability to offer rewards and impose costs as well as increase the likelihood of settlements.

Institutionalist research argues that states design institutions to make commitments credible, which in turn allows them to reap the benefits of cooperation (e.g., Koremenos, Lipson, and Snidal 2001). Our findings show that high levels of international institutionalization can have beneficial impacts both beyond the international level of analysis and the core issue of the respective IGO. Spillover and positive

\footnotetext{
${ }^{20}$ The result also holds $(p<0.01)$ among nonescalated conflicts only, by comparing decisive victories to settlements.

${ }^{21}$ Data for these analyses are from Cunningham et al. (2009) and Lujala (2009).
}

externality effects from HSIGO memberships for domestic conflict management are an important, nontrivial addition to the well-established arguments on international effects of institutional design.

This study also advances recent scholarship (e.g., Gleditsch 2007) by revealing a transnational conflictmanagement mechanism. The degree to which states are embedded in international institutional environments adds an important factor to this emerging research program: institutions are a substantial part of an international structure that, as we have shown, impacts the trajectory of civil conflicts. Finally, little effort has been made to link the low-level domestic violence and civil wars literatures. Treating the two phenomena as part of one trajectory is not only of academic interest but is also important for international policy. External actors likely have little influence on initial political protest turning violent. But there is an opportunity for international institutions to affect the further development of such episodes, by enhancing conflict-ending commitments and signaling negative external ramifications of prolonged violence.

\section{Acknowledgments}

We would like to thank Kyle Beardsley, Margit Bussmann, Courtenay Conrad, Page Fortna, Michael Greig, Håvard Hegre, Carmela Lutmar, Helen Milner, Sara Mitchell, Glenn Palmer, Burcu Savun, Geoffrey Wallace, our colleagues in the Department of Political Science at the University of Colorado Boulder, and the three anonymous reviewers for helpful feedback.

\section{References}

Abbott, Kenneth W., Robert Keohane, Andrew Moravcsik, Anne-Marie Slaughter, and Duncan Snidal. 2000. "The Concept of Legalization.” International Organization 54 (3): 401-19.

Aslam, Abid. 1999. "Donors Question Violence in East Timor." Inter Press Service. September 3, 1999. http://ipsnews.net/ print.asp?idnews=78213 (March 21, 2012).

Balch-Lindsay, Dylan, and Andrew J. Enterline. 2000. "Killing Time: The World Politics of Civil War Duration, 1820-1992." International Studies Quarterly 44 (4): 615-42.

BBC News. 1999. "IMF Suspends Talks with Indonesia." September 19, 1999. http://news.bbc.co.uk/2/hi/business/ 442969.stm (August 21, 2011).

Bearce, David H., and Stacy Bondanella. 2007. "Intergovernmental Organizations, Socialization, and Member-State Interest Convergence." International Organization 61 (4): 703-33.

Bennett, D. Scott, and Allan C. Stam. 2000. "Eugene: A Conceptual Manual." International Interactions 26 (2): 179-204.

Blattman, Christopher, and Edward Miguel. 2010. "Civil War." Journal of Economic Literature 48 (1): 3-57. 
Boehmer, Charles, Erik Gartzke, and Timothy Nordstrom. 2004. "Do Intergovernmental Organizations Promote Peace?" World Politics 57 (1): 1-38.

Cameron, Charles M. 2000. Veto Bargaining: Presidents and the Politics of Negative Power. Cambridge: Cambridge University Press.

Cederman, Lars-Erik, Brian Min, and Andreas Wimmer. 2009. "Ethnic Power Relations Dataset." May 1, 2009. http:// hdl.handle.net/1902.1/11796 (March 15, 2012).

Collier, Paul, V.L. Elliott, Håvard Hegre, Anke Hoeffler, Marta Reynal-Querol, and Nicholas Sambanis. 2003. Breaking the Conflict Trap: Civil War and Development Policy. Washington, DC: World Bank.

Collier, Paul, and Anke Hoeffler. 2004. "Greed and Grievance in Civil War." Oxford Economic Papers 56 (4): 563-95.

Cunningham, David E., Kristian Skrede Gleditsch, and Idean Salehyan. 2009. "It Takes Two: A Dyadic Analysis of Civil War Duration and Outcome." Journal of Conflict Resolution 53 (4): 570-97.

Diehl, Paul F. 2008. Peace Operations. Cambridge, UK: Polity.

Donno, Daniela. 2010. "Who Is Punished? Regional Intergovernmental Organizations and the Enforcement of Democratic Norms." International Organization 64 (4): 593-625.

Doyle, Michael W., and Nicholas Sambanis. 2000. "International Peacebuilding: A Theoretical and Quantitative Analysis." American Political Science Review 94 (4): 779-801.

Fausett, Elizabeth, and Thomas J. Volgy. 2010. "Intergovernmental Organizations and Interstate Conflict: Parsing out IGO Effects for Alternative Dimensions of Conflict in Postcommunist Space.” International Studies Quarterly 54 (1): 79-101.

Fearon, James D. 2007. "Fighting Rather Than Bargaining." Typescript. Stanford University.

Fearon, James D., and David D. Laitin. 2003. "Ethnicity, Insurgency, and Civil War." American Political Science Review 97 (1): 75-90.

Fidler, Stephen, and Gwen Robinson. 1999. IMF and World Bank Played Role in Climbdown. Financial Times. September 13, 1999.

Fortna, V. Page. 2004. "Does Peacekeeping Keep Peace? International Intervention and the Duration of Peace after Civil War." International Studies Quarterly 48 (2): 269-92.

Gleditsch, Kristian Skrede. 2002. "Expanded Trade and GDP Data." Journal of Conflict Resolution 46 (5): 712-24.

Gleditsch, Kristian Skrede. 2007. "Transnational Dimensions of Civil War." Journal of Peace Research 44 (3): 293-309.

Gleditsch, Nils Petter, Peter Wallensteen, Mikael Eriksson, Margareta Sollenberg, and Håvard Strand. 2002. "Armed Conflict 1946-2001: A New Dataset." Journal of Peace Research 39 (5): 615-37.

Goldstone, Jack A., Robert H. Bates, David L. Epstein, Ted R. Gurr, Michael B. Lustik, Monty G. Marshall, Jay Ulfelder, and Mark Woodward. 2010. "A Global Model for Forecasting Political Instability." American Journal of Political Science 54 (1): 190-208.

Greig, J. Michael. 2005. "Stepping into the Fray: When Do Mediators Mediate?" American Journal of Political Science 49 (2): 249-66.

Greig, J. Michael, and Patrick M. Regan. 2008. "When Do They Say Yes? An Analysis of the Willingness to Offer and Accept Mediation in Civil Wars." International Studies Quarterly 52 (4): 759-81.
Hafner-Burton, Emilie M. 2005. "Trading Human Rights: How Preferential Trade Agreements Influence Government Repression." International Organization 59 (3): 593-629.

Hajari, Nisid. 1999. “The Hard Part.” Time Magazine. September 27, 1999. http://edition.cnn.com/ASIANOW/time/magazine/ 99/0927/east_timor.html. (August 21, 2011).

Heckman, James J. 1979. "Sample Selection Bias as a Specification Error." Econometrica 47 (1): 153-61.

Hoddie, Matthew, and Caroline Hartzell. 2003. "Civil War Settlements and the Implementation of Military Power-Sharing Arrangements." Journal of Peace Research 40 (3): 303-20.

Human Rights Watch. 1999. "Indonesia and East Timor." Human Rights Watch World Report 2000. December 1, 1999. http://www.unhcr.org/refworld/docid/3ae6a8c610.html. (March 21, 2012).

International Monetary Fund. 1999. "The Situation in Indonesia and the IMF." IMF News Release. September 16, 1999. http:// www.imf.org/external/np/vc/1999/091699.htm. (March 21, 2012).

Koremenos, Barbara, Charles Lipson, and Duncan Snidal. 2001. "The Rational Design of International Institutions." International Organization 55 (4): 761-99.

Kreutz, Joakim. 2010. "How and When Armed Conflicts End: Introducing the UCDP Conflict Termination Dataset." Journal of Peace Research 47 (2): 243-50.

Lacina, Bethany, and Nils Petter Gleditsch. 2005. "Monitoring Trends in Global Combat: A New Dataset of Battle Deaths." European Journal of Population 21 (2-3): 145-66.

Lujala, Paivi. 2009. "Deadly Combat over Natural Resources." Journal of Conflict Resolution 53 (1): 50-71.

Marshall, Monty G., and Keith Jaggers. 2002. "Polity IV Project: Dataset Users' Manual." College Park: University of Maryland.

Martin, Ian. 2001. Self-Determination in East Timor: The United Nations, the Ballot, and International Intervention. Boulder, CO: Lynne Rienner.

Mattes, Michaela, and Burcu Savun. 2010. "Information, Agreement Design, and the Durability of Civil War Settlements." American Journal of Political Science 54 (2): 511-24.

Metternich, Nils W. 2011. "Expecting Elections: Interventions, Ethnic Support, and the Duration of Civil Wars." Journal of Conflict Resolution 55 (6): 909-37.

Mitchell, Sara McLaughlin, and Paul R. Hensel. 2007. "International Institutions and Compliance with Agreements." American Journal of Political Science 51 (4): 721-37.

Oneal, John R., Bruce Russett, and Michael L. Berbaum. 2003. "Causes of Peace: Democracy, Interdependence, and International Organizations, 1885-1992.” International Studies Quarterly 47 (3): 371-93.

Orford, Anne. 2003. Reading Humanitarian Intervention: Human Rights and the Use of Force in International Law. Cambridge: Cambridge University Press.

Pevehouse, Jon. 2002. "Democracy from the Outside-In? International Organizations and Democratization." International Organization 56 (3): 515-49.

Pevehouse, Jon, Timothy Nordstrom, and Kevin Warnke. 2004. "The COW-2 International Organizations Dataset Version 2.0." Conflict Management and Peace Science 21 (2): 101-19.

Raleigh, Clionadh, and Håvard Hegre. 2009. "Population Size, Concentration, and Civil War. A Geographically Disaggregated Analysis.” Political Geography 28 (4): 224-38.

Regan, Patrick M. 2002. "Third-Party Interventions and the Duration of Intrastate Disputes." Journal of Conflict Resolution 46 (1): 55-73. 
Regan, Patrick M., Richard W. Frank, and Aysegul Aydin. 2009. "Diplomatic Interventions and Civil War: A New Dataset." Journal of Peace Research 46 (1): 135-46.

ReliefWeb. 1999. "World Bank Statement on East Timor, September 7, 1999." World Bank Report. September 7, 1999. http://reliefweb.int/node/52142. (March 21, 2012).

Russett, Bruce, John R. Oneal, and David R. Davis. 1998. “The Third Leg of the Kantian Tripod for Peace: International Organizations and Militarized Disputes, 1950-1985." International Organization 52 (3): 441-68.

Salehyan, Idean, and Kristian Skrede Gleditsch. 2006. "Refugees and the Spread of Civil War." International Organization 60 (2): 335-66.

Sarkees, Meredith Reid. 2000. "The Correlates of War Data on War: An Update to 1997." Conflict Management and Peace Science 18 (1): 123-44.

Shannon, Megan. 2009. "Preventing War and Providing the Peace? International Organizations and the Management of Territorial Disputes." Conflict Management and Peace Science 26 (2): 144-63.

Simmons, Beth A., and Allison Danner. 2010. "Credible Commitments and the International Criminal Court." International Organization 64 (1): 225-56.

Themnér, Lotta, and Peter Wallensteen. 2011. "Armed Conflict, 1946-2010.” Journal of Peace Research 48 (4): 525-36.
Thornton, Philip. 1999. "World Bank Freezes All New Loans to Indonesia." The Independent. September 14, 1999. http:// www.independent.co.uk/news/business/world-bank-freezes-allnew-loans-to-indonesia-1119048.html. (August 21, 2011).

Walter, Barbara F. 1999. "Designing Transitions from Civil War." International Security 24 (1): 127-55.

Walter, Barbara F. 2009. "Bargaining Failures and Civil War." Annual Review of Political Science 12 (1): 243-61.

Weingast, Barry R. 1996. "Off-the-Path Behavior". In Counterfactual Thought Experiments in World Politics, eds. Philipp Tetlock and Aaron Belkin. Princeton, NJ: Princeton University Press.

Wheeler, Nicholas J., and Tim Dunne. 2001. "East Timor and the New Humanitarian Interventionism." International Affairs 77 (4): 805-27.

Johannes Karreth is a Ph.D. candidate in the Department of Political Science at the University of Colorado Boulder, Boulder, CO 80309.

Jaroslav Tir is an Associate Professor in the Department of Political Science at the University of Colorado Boulder, Boulder, CO 80309. 